7. Reprod. Fert. (1966) 12, 591-592

BRIEF COMMUNICATION

\title{
THE CHROMOSOMES OF GOAT × SHEEP HYBRIDS
}

\author{
J. L. HANCOCK AND PATRIGIA A. JAGOBS \\ A.R.C. Animal Breeding Research Organization, Edinburgh, and M.R.C. Clinical \\ Effects of Radiation Research Unit, Western General Hospital, Edinburgh
}

(Received 17th July 1966)

It has been known for many years (Warwick, Berry \& Horlacher, 1932, 1933, 1934) that goats readily conceive when inseminated with ram semen but that the hybrid embryos fail to survive beyond the second month of pregnancy. Berry (1938) concluded from an examination of cells from the hybrid amnion that the death of the foetus was unlikely to be due to abnormalities of cell division. The sheep has fifty-four chromosomes comprising six metacentric chromosomes and forty-eight acrocentric chromosomes, while the goat has sixty chromosomes all of which are acrocentric. Berry found the chromosome number of the hybrid to be fifty-seven, but he noted only two metacentric chromosomes.

Berry's illustrations give clear evidence that the techniques available to him yielded preparations greatly inferior to those produced by modern techniques. It therefore seemed important to examine Berry's conclusion using the improved technique available now. In a preliminary study of preparations made from cultured hybrid embroyos (Buttle \& Hancock, 1966) it was confirmed that the embryo has fifty-seven chromosomes. However, several cells were counted with both more and with less than the modal number and the hybrid was found to have the expected number of three metacentric chromosomes. In view of the possibility that these anomalies might be artifacts of tissue culture, it seemed important to examine dividing cells directly from the hybrid so that any changes due to culture could be excluded. The chromosomes of ten hybrid embryos, two sheep embryos and two goat embryos have been examined in this way and the findings show no evidence of chromosome irregularity which could explain the death of the hybrid.

Goats were tried daily for onset of heat with a vasectomized male and inseminated with fresh undiluted ram semen on the day of acceptance and on the day following. Embryos were removed at laparotomy 24 to 33 days after the first insemination. The embryos were removed from the uterus within the intact amniotic sac to a sterile petri dish. The excised liver and surrounding tissues were immediately placed in Eagle's tissue culture medium containing $0.002 \%$ colcemid and a cell suspension was prepared by repeated aspiration with hypodermic needle and syringe. The cells were left in suspension for approximately $1 \frac{1}{2} \mathrm{hr}$ either at room temperature or at $37^{\circ} \mathrm{C}$, and then processed as follows. 
The suspension was first centrifuged at approximately $1000 \mathrm{rev} / \mathrm{min}$. After discarding the supernatant, the cells were re-suspended in $0.95 \%$ sodium citrate and left for $20 \mathrm{~min}$ at $37^{\circ} \mathrm{G}$. The cells were fixed by addition of fixative (acetic acid-methyl alcohol 1:3) either to the citrate suspension or to the cells after removal of the citrate by cenrifugation. Addition of fixative before centrifugation prevented clumping of the cells. The fixative was changed twice and the cells were re-suspended in two changes of $60 \%$ acetic acid. A drop of this suspension was placed on a clean microscope slide, the slide was then dried by waving vigorously over a spirit-flame. Considerable heat was needed to spread the cells. Slides were stained in $2 \%$ acetic-orcein, dehydrated, cleared and mounted.

Cells from ten hybrid embryos 24 to 31 days old were examined. Three showed clear evidence of a Y chromosome (see Borland, 1964) and were judged to be males; the remaining seven were assumed to be females. Counts were made on a total of 135 cells. Of these, 125 were found to have fifty-seven chromosomes, eight had fifty-six chromosomes, one cell was found with fifty-five and one with fifty-eight chromosomes. All 135 cells had three large metacentric chromosomes. A further 116 cells were scored for the number of metacentric chromosomes present and all these also showed three metacentric chromosomes. A total of 2636 dividing cells were seen on the preparations and of these twenty-six were polyploid.

Of thirty cells counted from two 29-day-old male sheep embryos, twenty-four had fifty-four chromosomes; the remainder had fifty-three (three cells) fiftytwo or less (two cells) and fifty-seven chromosomes (one cell). All cells had six metacentric chromosomes. Seventeen of the 1064 dividing cells seen on the preparations were polyploid.

Of twenty-three goat cells from two 33-day-old male embryos, seventeen had sixty chromosomes, the remainder had fifty-seven (one cell), fifty-nine (three cells) or sixty-one chromosomes (two cells) No metacentric chromosomes were seen. Six of the 858 dividing cells seen were polyploid.

Our results show no evidence of abnormalities of chromosome number or structure which could have contributed to the death of the embryo. The findings support the conclusion reached by Berry that the death of the hybrid cannot be explained on cytological grounds.

We want to thank Muriel Brunton and Moira Rennie for skilled technical assistance.

\section{REFERENCES}

BERRY, R. O. (1938) Comparative studies on the chromosome number in sheep, goats and sheep/ goat hybrids. 7. Hered. 29, 343.

BorLand, J. (1964) The chromosomes of domestic sheep. F. Hered. 55, 61.

Butrle, H. L. \& HANCOCK, J. L. (1966) The chromosomes of goats, sheep and their hybrids. Res. vet. Sci. 7, 230.

Warwick, B. L., Berry, R. O. \& Horlacher, W. R. (1932) Cytological and hybridization studies with sheep and goats. Rep. Tex. agric. Exp. Stn, p. 24.

Warwick, B. L., BerRy, R. O. \& HorLacher, W. R. (1933) Cytological and hybridization studies with sheep and goats. Rep. Tex. agric. Exp. Stn, p. 29.

Warwick, B. L., Berry, R. O. \& Horlacher, W. R. (1934) Cytological and hybridization studies with sheep and goats. Rep. Tex. agric. Exp. Stn, p. 30. 